\title{
Choosing a Career Based Personality Matching: A Case Study of King Abdulaziz University
}

\author{
Nahla Aljojo \\ Faculty of Computing and Information Technology, Information Systems Department, \\ King Abdulaziz University, P.O. Box, 132139, Jeddah, 21382, Saudi Arabia
}

\begin{abstract}
Traditionally, selecting a career involved matching the specific aptitudes and characteristics of an individual with a career which required or involved such factors. This particular approach has as its foundation the fact that certain careers have need of individuals with certain skills and attitudes, that is to say the individual is a 'fit' for that particular career based on their knowledge, skill and disposition. Many students have problems determining their college majors and a suitable career. This paper shows how to find a career that fits one's personality, and aims to help students analyse their personalities based on the Holland personality test. This paper will identify the most suitable career for students by using a validated Arabic version of the Holland survey, which is one of the most popular models used for career personality tests. This study implements a new set of tasks, testing 117 students from King Abdulaziz University with the Arabic version of the Holland test. The test was applied to female students from three majors, computer science, information systems, and preparatory year distance learning students. The implications of the test results will help students to understand their personality types and determine a suitable career, as the results of the test suggest suitable careers for students which match their personalities. Ultimately, the results show a difference between computer science, information systems and preparatory year distance learning students with regard to personality types and suitable careers.
\end{abstract}

Keywords-Holland's Theory of Vocational Personalities; RIASEC personality and environment types; occupational interests; Career change; hexagonal model

\section{INTRODUCTION}

Historically, the selection of an occupation or career might have been considered as less difficult and more straightforward many years ago, before the industrial revolution. Often an individual's career was simply determined by following in their father's footsteps, that is to say a carpenter's son would become a carpenter, and a cobbler's son would learn to be a cobbler like his father, while the nobility and landed gentry groomed their offspring to become future leaders. Over time, and especially since the industrial revolution, this process of young people choosing their occupation or career has changed dramatically and become far more complex. Wider access to higher levels of education, women entering the workforce and the swing from industrialization to service-based industries in many developed economies have all had an impact on how an individual chooses their occupation or career. In this postindustrialization period, where a higher level of skills is generally required due to the emergence of knowledge working and knowledge based industries, individuals might have greater choice than ever before regarding their careers, but the extensive opportunities when choosing the right career also present challenges. With this in mind, research which allows students to make informed decisions regarding their professional lives, and therefore their future personal lives (Zaidi et al., 2012) is essential in order to ensure that students fully understand this complex process and how it might impact their lives in the future.

This paper has been designed to find a career that fits one's personality. The Holland test was developed as a technique to help determine a suitable career according to the six aforementioned personality types (Holland's theory). Furthermore, this paper compares personality types, and suitable careers that fit these personality types, of students from computer science (CS), information systems (IS), and first year distance learning students within Saudi Arabia.

The author chose female students from different departments at the Faculty of Computing and Information Technology, King Abdulaziz University. These students came from the departments of CS, IS, and preparatory year of distance learning, in order to determine suitable careers for them according to the six personality types. The author subjected the students to a test consisting of 106 questions, and then calculated and analysed the results by using SPSS. The results showed that the optimal solution was the Holland test, used by normal students to help them better understand their personalities. The advantages of this solution are the time and effort saved, its ease of use, and that it can be understood and applied anytime and anywhere

\section{LITERATURE REVIEW}

The aim of recruitment is to select the best possible applicant who has the capacities that are needed for the job and who will fit in well with the organization (Rynes \& Gerhart, 1990). The most common theory used in employee selection processes is perhaps the theory of fit (Sekiguchi, 2004). During the past century, models of fit or congruence have achieved a significant role in the field of industrial and organizational psychology and human resources management (Saks \& Ashforth, 1997; Schneider, 1987, 2001; Holland, 1997; Kristof, 1996; Pervin, 1968; Ekehammer, 1974; Lewin, 1935; Murray, 1938; Parsons, 1909). Employee selection processes have especially focused on achieving person-job fit (Werbel \& Gilliland, 1999) which is the congruence between the abilities of a person and the demands of a job (Edwards, 1991; Kristof, 1996). During the past decade or so, several authors have recognized that the practitioner involved in personnel selection and those involved in scientific studies of this discipline have 
diverged and are moving further and further away from each other (e.g. Anderson, Herriot \& Hodgkinson, 2001; Dunnette, 1990; Hodgkinson, Herriot \& Anderson, 2001; Sackett, 1994). One example of this trend is that the American Uniform Guidelines on Employee Selection Procedures (1978), Harvey (1991) and Harvey and Wilson (2000) recommend that the traits and abilities of workers should be left out of selection processes. According to them, personal traits do not meet the requirements of verifiable and replicable job analysis data.

There are various factors which drive the decision to choose any particular career. Davidson (2010) identified environment as being of importance, as well as remuneration, proximity to family, and personality. Earlier, Borchert (2002) in a study of students at high school highlighted the factors of personality, opportunities, and environment as being the fundamental drivers of decision making regarding a career. However, the overriding factor determining career selection was in fact the personal desire and disposition of a student to select a particular career.

The view that individuals should select a career in line with their personality was also supported by Ferguson (2000) who listed six basic vocational interests which included social, investigative, realistic, enterprising, artistic and conventional (SIREAC types) referred to as Holland Typology. Ferguson claimed that individuals can typically be classified as one of these personality types. His recommendation was that an individual should consider careers which provided a good match in terms of the environment offered and their own personality type. His conclusion was that a greater level of congruence between personality traits, personal interest and the environment offered by a particular career would lead to a higher level of professional and personal satisfaction.
Parental profession affects the choice of career, as it is the closest influence an individual normally has. High school coursework, higher education and vocational training opportunities also influence career decisions. But most of all it is an individual's personality which plays the most important role when choosing a career. Students tend to opt for careers which are similar to their personalities (Schreiner, 2010). Gioia (2010) explained the reasons why people make bad career choices. She discussed various reasons why people selected unsuitable careers, such as parental expectations, peer pressure, uninformed decision making and poor self-image.

\section{Holland OCCUPATIONAL THEMES (RIASEC)}

Holland's (1985) theory of jobs describes a person's personality as being one of six main types - realistic, conventional, enterprising, investigative, social, and artistic. Holland suggests that most individuals belong to one of six main types. Along with these types, an individual has a singular identity, which might reflect interests, values, abilities, and/or fantasies (Miller, 1994). Holland expounded his hypothesis and focused around his experience as an academic and instructor. His experience allowed him to decide how people might be re-grouped into different types focused on their profession. This methodology created a relationship between different working environments, singular identities, and the career decision process and its advancement (John, 1997).

Holland's codes, both individual and environmental, are communicated in three-letter codes. A three-letter code is created by selecting the three main types among the most suitable categories for the selected person from Holland's six main types.

\section{TABLE I. HOLland's PERSONALity StYles (SOURCE: ADAPTED FROM CRUiCKSHANK (2005))}

\begin{tabular}{|c|c|}
\hline Type & Personality \\
\hline $\begin{array}{l}\text { Realistic(Adventuring/ } \\
\text { Producing) }\end{array}$ & $\begin{array}{l}\text { These people prefer manual occupations which require working with their hands, tools, machines, and technology, and they } \\
\text { have a narrow scope of interests with a closed system of beliefs and values. In troubleshooting and problem solving, they prefer } \\
\text { practical and structured solutions. } \\
\text { Preferred vocation: automotive engineer, Boiler maker, Electrician, and Farmer }\end{array}$ \\
\hline $\begin{array}{l}\text { Investigative } \\
\text { (Analytic) }\end{array}$ & $\begin{array}{l}\text { These people prefer occupations which work with ideas, examination, watching, understanding, and controlling processes. This } \\
\text { type of person does not enjoy social and business activities. In troubleshooting and problem solving, they depend on thinking, } \\
\text { collecting data, and making careful analyses. } \\
\text { Preferred vocation: computer operator, laboratory technician and mathematics teacher }\end{array}$ \\
\hline Artistic (Creative) & $\begin{array}{l}\text { These people prefer occupations requiring activities which are ambiguous, unsystematic, disordered, or use materials to produce } \\
\text { creative art. This type of person does not enjoy systematic, orderly, or monotonous activities. In troubleshooting and problem } \\
\text { solving, they demonstrate inventive, creative, and artistic competencies } \\
\text { Preferred vocation: actor/actress, artist, interior decorator, photographer }\end{array}$ \\
\hline Social (Helping) & $\begin{array}{l}\text { These people prefer activities which control others in an attempt to cure, teach, develop, or train them. This type of person does } \\
\text { not enjoy systematic, orderly, or monotonous activities. In troubleshooting and problem solving, they show dominant human } \\
\text { interaction and social competencies. } \\
\text { Preferred vocation: funeral director, librarian, minister/priest, social sciences teacher }\end{array}$ \\
\hline $\begin{array}{l}\text { Enterprising } \\
\text { (Influencing) }\end{array}$ & $\begin{array}{l}\text { These people prefer activities which control others in an attempt to reach organisational goals or achieve economic gain. This } \\
\text { type of person does not enjoy scientific or intellectual tasks. } \\
\text { Preferred vocation: contractor, lawyer, radio/TV announcer, real estate, sales person }\end{array}$ \\
\hline $\begin{array}{l}\text { Conventional } \\
\text { (Organising) }\end{array}$ & $\begin{array}{l}\text { These people prefer occupations which deal with data, ordering written or numerical data, organising things, or performing } \\
\text { systematic activities. This type of person does not enjoy artistic, ambiguous, or exploratory tasks. In troubleshooting and } \\
\text { problem solving, they follow established rules and look for advice or counsel. } \\
\text { Preferred vocation: bookkeeper, key punch operator, post office clerk, typist }\end{array}$ \\
\hline
\end{tabular}


The individual's work nature is based on the three-letter code and gives a short summary of what the person is good at by explaining the level of similarity to the three words together. For example, the three-letter code 'CER' indicates that the individual has an overwhelming conventional identity and characteristics of enterprise and realism (Miller, 1994 (Table 1 summaries the six Holland types, according to Cruickshank (2005)).

Holland developed a hexagonal model in order to show connections linking personality types as well as define the notions of differentiation and consistency. The former is considered as the degree to which a personality pattern can be described. The latter is considered as the extent of association which exists between different personality types in an individual. An example of this would be personality pattern RI, which has greater consistency than CA. Additional high consistency patterns also include RC, IA, AS and SE. Medium consistency patterns include IS, IC, AR, and SC, while low consistency patterns include RS, EI, AC and SR. Patterns which are easy to distinguish are those which bear a high degree of resemblance to one single personality type (Kelso et al., 1986). Those which are not so easily distinguishable or more difficult to classify might bear equal resemblance to a number of the six types of personality. Based on this, Holland claimed that the main personality characteristic of a person, corresponding to their type, was the most important driver in terms of choosing their vocation. Holland's theory extended to claiming that personality types flourish in a congruent environment, that is to say a congruent environment offers prospects and incentives which fit well with a person's own likes, interests and skills, in other words, a Realistic type in a Realistic environment (Holland, 1985).

The notion of forecasting results based on the matching of personality type with environment was based on the fact that personality types and environments had a mutual range of factors which made it possible to forecast the outcome of a certain type of person in a certain type of environment (Holland, 1985, p.34). It was also suggested (Holland, 1985, p.35) that placing a specific personality type within an appropriate and matched environment would lead to a range of beneficial outcomes, for example, a higher degree of satisfaction at work, greater accomplishments, as well as vocational longevity.

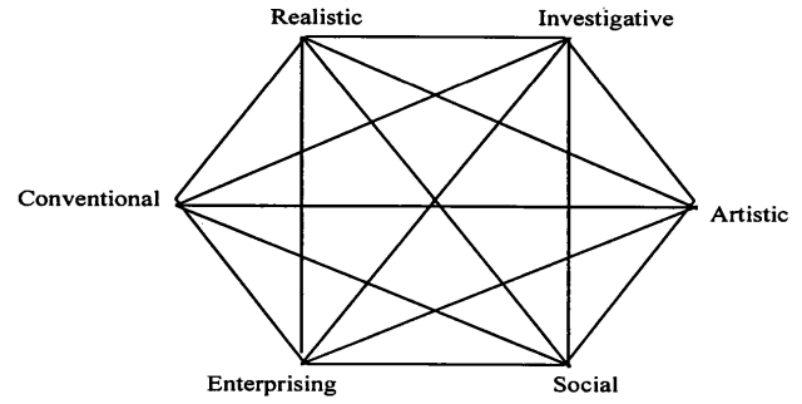

Fig. 1. Holland's Hexagonal Model for defining the psychological resemblances among personality types, environments and their interaction (Source: Holland 1985, p.29)

\section{METHODOLOGY}

\section{A. Participation}

The participants in this study were 117 women, aged $20-40$ years old. All participants were students from King Abdulaziz University, with 28 CS students, 27 IS students (Faculty of Computing and Information Technology), and62 preparatory year distance learning students.

\section{TABLE II. RIASEC QUESTIONS}

\begin{tabular}{|c|c|c|c|c|c|c|c|c|c|c|c|c|c|c|}
\hline \multirow{2}{*}{ A } & 1 & 4 & 14 & 17 & 32 & 33 & 35 & 40 & 47 & 49 & 58 & 68 & 80 & 81 \\
\hline & 90 & 91 & 102 & 105 & & & & & & & & & & \\
\hline \multirow{2}{*}{ C } & 2 & 12 & 24 & 27 & 38 & 39 & 56 & 57 & 70 & 71 & 79 & 83 & 86 & 87 \\
\hline & 92 & 103 & & & & & & & & & & & & \\
\hline \multirow{2}{*}{ I } & 13 & 16 & 18 & 19 & 25 & 29 & 43 & 44 & 48 & 50 & 52 & 60 & 66 & 73 \\
\hline & 76 & 77 & 93 & 98 & & & & & & & & & & \\
\hline \multirow{2}{*}{ E } & 9 & 11 & 20 & 21 & 30 & 34 & 41 & 51 & 53 & 55 & 61 & 69 & 74 & 75 \\
\hline & 89 & 95 & 97 & 106 & & & & & & & & & & \\
\hline \multirow{2}{*}{$\mathrm{R}$} & 3 & 8 & 10 & 15 & 26 & 31 & 36 & 37 & 42 & 45 & 54 & 65 & 82 & 85 \\
\hline & 96 & 99 & 100 & 101 & & & & & & & & & & \\
\hline \multirow{2}{*}{ S } & 5 & 6 & 7 & 22 & 23 & 28 & 46 & 59 & 62 & 63 & 64 & 67 & 72 & 78 \\
\hline & 84 & 88 & 94 & 104 & & & & & & & & & & \\
\hline
\end{tabular}

\section{B. Intrsuments}

The Holland test consists of 106 questions, each question requiring a simple yes or no response. Each of the sets of questions corresponds to one of the six personality types discussed above - Realistic (R), Investigative (I), Artistic (A), Social (S), and Enterprising (E). Conventional (C) includes only 16 questions. The division of questions can be seen below in Table II. For all questions, the students were given two possible answers - either yes or no - for each question.

The three highest categories represent the areas which have a high level of interest for a student and are compatible with a student's Holland Code. An example of this would be a student whose highest score is in the Social category, their second highest score is in the Artistic category, and their third highest score is in the Enterprising category: which would result in their Holland Code being SAE, indicating that they should focus their career choice in occupational areas related to this.

\section{Procedure}

A validated Arabic version of the Holland survey was uploaded to blackboard (Learning Management System) for students of preparatory year distance learning. Students then 
sent the completed Holland survey back by email. In the case of students from CS and IS, a validated Arabic version of the Holland survey was distributed manually to them and then collected manually once they had completed it.

\section{RESULTS}

\section{A. Descriptive Statistics}

As seen in Table III, Descriptive statistics of the participants (students of CS, IS and preparatory year distance learning), the results according to personality styles were as follows:

- Social was the most frequent, representing $19 \%$ of the overall personality styles of students

- Enterprising was assigned the second rank, representing $16.8 \%$ of the overall personality styles of students

- Investigative was assigned the third rank, representing $16.4 \%$ of the overall personality styles of students

- Conventional was assigned the fourth rank, representing $16.2 \%$ of the overall personality styles of students

- Artistic was assigned the fifth rank, representing $16.1 \%$ of the personality styles of students

- Realistic was the lowest, representing $15.3 \%$ of the overall personality styles of students

- CES was the most frequent of the three highest, representing $44.4 \%$ of the overall personality styles of students

- ESA was assigned the second rank, representing $41.0 \%$ of the overall personality styles of students

- SAI was assigned the third rank, representing $32.5 \%$ of the overall personality styles of students

- IRC was assigned the fourth rank, representing $16.2 \%$ of the overall personality styles of students

- AIR was assigned the fifth rank of the three highest, representing $15.4 \%$ of the personality styles of students

- $\mathrm{RCE}$ was the least frequent, representing $12.8 \%$ of the overall personality styles of students

TABLE III. DESCRIPTIVE STATISTICS OF THE PARTICIPANTS (STUDENTS OF CS, IS AND PREPARATORY YEARDISTANCE LEARNING) ACCORDING TO PERSONALITY STYLES

\begin{tabular}{|c|c|c|c|c|}
\hline Personality Styles & Mean & Std. Deviation & Percent & $\mathbf{N}$ \\
\hline $\mathbf{S}$ & 13.34 & 2.72 & 19.12 & \multirow{12}{*}{11} \\
\hline $\mathbf{E}$ & 11.76 & 3.23 & 16.84 & \\
\hline I & 11.45 & 3.14 & 16.40 & \\
\hline $\mathbf{C}$ & 11.32 & 2.76 & 16.21 & \\
\hline $\mathbf{A}$ & 11.26 & 2.77 & 16.12 & \\
\hline $\mathbf{R}$ & 10.70 & 2.69 & 15.32 & \\
\hline AIR & 0.15 & 0.36 & 15.4 & \\
\hline ESA & 0.41 & 0.49 & 41.0 & \\
\hline CES & 0.44 & 0.50 & 44.4 & \\
\hline SAI & 0.32 & 0.47 & 32.5 & \\
\hline RCE & 0.13 & 0.34 & 12.8 & \\
\hline IRC & 0.16 & 0.37 & 16.2 & \\
\hline
\end{tabular}

As seen in Table IV, Descriptive statistics of the CS participants according to their personality styles, the results were as follows:

- CES was the most frequent, representing $48.1 \%$ of the overall personality styles of CS students

- SAI was assigned the second rank, representing 33.3\% of the overall personality styles of CS students

- ESA was assigned the third rank, representing $29.5 \%$ of the overall personality styles of CS students

- IRC was assigned the fourth rank, representing $22.2 \%$ of the overall personality styles of CS students

- AIR was assigned the fifth rank, representing $14.8 \%$ of the personality styles of CS students

- RCE was the least frequent, representing $11.1 \%$ of the overall personality styles of CS students

TABLE IV. DESCRIPTIVE STATISTICS OF THE CS PARTICIPANTS ACCORDING TO THEIR PERSONALITY STYLES

\begin{tabular}{|c|c|c|c|c|}
\hline $\begin{array}{l}\text { Personality } \\
\text { Styles (CS } \\
\text { students) }\end{array}$ & Mean & $\begin{array}{l}\text { Std. } \\
\text { Deviation }\end{array}$ & Percent & $\mathbf{N}$ \\
\hline CES & .48 & .51 & 48.1 & \multirow{6}{*}{27} \\
\hline SAI & .33 & .48 & 33.3 & \\
\hline ESA & .30 & .47 & 29.6 & \\
\hline IRC & .22 & .42 & 22.2 & \\
\hline AIR & .15 & .36 & 14.8 & \\
\hline RCE & .11 & 32 & 11.1 & \\
\hline
\end{tabular}

As seen in Table V, Descriptive statistics of the IS participants according to their personality styles, the results were as follows:

- CES was the most frequent, representing $28.6 \%$ of the overall personality styles of IS students

- SAI, ESA and AIR were assigned the second rank, representing $25.0 \%$ of the overall personality styles of IS students

- IRC and RCE were the least frequent, representing $14.3 \%$ of the overall personality styles of IS students

TABLE V. DESCRIPTIVE STATISTICS OF THE IS PARTICIPANTS ACCORDING TO THEIR PERSONALITY STYLES

\begin{tabular}{|c|c|c|c|c|}
\hline $\begin{array}{l}\text { Personality } \\
\text { Styles (IS } \\
\text { students) }\end{array}$ & Mean & $\begin{array}{l}\text { Std. } \\
\text { Deviation }\end{array}$ & Percent & $\mathbf{N}$ \\
\hline CES & .29 & .46 & 28.6 & \multirow{6}{*}{28} \\
\hline SAI & .25 & .44 & 25.0 & \\
\hline ESA & .25 & .44 & 25.0 & \\
\hline AIR & .25 & .44 & 25.0 & \\
\hline IRC & .14 & .36 & 14.3 & \\
\hline RCE & .14 & .36 & 14.3 & \\
\hline
\end{tabular}

As seen in Table VI, Descriptive statistics of the preparatory year distance learning participants according to their personality styles, the results were as follows:

- ESA was the most frequent, representing 53.2\% of the overall personality styles of distance learning students 
- CES was assigned the second rank, representing 50.0\% of the overall personality styles of distance learning students

- SAI was assigned the third rank, representing $35.5 \%$ of the overall personality styles of distance learning students

- IRC was assigned the fourth rank, representing $14.5 \%$ of the overall personality styles of distance learning students

- RCE was assigned the fifth rank, representing $12.9 \%$ of the personality styles of distance learning students

- AIR was the least frequent, representing $11.3 \%$ of the overall personality styles of distance learning students

TABLE VI. DESCRIPTIVE STATISTICS OF THE PREPARATORY YeAR OF DistanCE LEARNING PARTICIPANTS ACCORDING TO THEIR PERSONALITY STYLES

\begin{tabular}{|l|l|l|l|l|}
\hline $\begin{array}{l}\text { Personality Styles (first } \\
\text { year of Distance } \\
\text { learning students) }\end{array}$ & Mean & $\begin{array}{l}\text { Std. } \\
\text { Deviation }\end{array}$ & Percent & N \\
\hline ESA & .53 & .50 & 53.2 & \\
\cline { 1 - 4 } CES & .50 & .50 & 50.0 & \multirow{2}{*}{62} \\
\hline SAI & .35 & .48 & 35.5 & \\
\hline IRC & .15 & .36 & 14.5 & \\
\cline { 1 - 3 } & .13 & .34 & 12.9 & \\
\hline AIR & .11 & .32 & 11.3 & \\
\hline
\end{tabular}

B. Correlation Analysis

As seen in Table VII, inter-correlations among Holland's personality styles are as follows:

- Realistic which correlated positively with Artistic, Social, Enterprising and Investigative

- Artistic which correlated positively with Realistic, Conventional, Social, Enterprising and Investigative

- Conventional which correlated positively with Artistic, Social, Enterprising and Investigative

- Social which correlated positively with Realistic, Artistic, Conventional, Enterprising and Investigative

- Enterprising which correlated positively with Realistic, Artistic, Conventional, Social and Investigative

- Investigative which correlated positively with Realistic, Artistic, Conventional, Social and Enterprising

TABLE VII. INTER-CORRELATIONS AMONG HOLLAND’s PERSONALITY STYLES

\begin{tabular}{|c|c|c|c|c|c|c|}
\hline $\begin{array}{l}\text { Personality } \\
\text { Styles }\end{array}$ & $\mathbf{R}$ & $\mathbf{A}$ & $\mathbf{C}$ & $\mathbf{S}$ & $\mathbf{E}$ & I \\
\hline $\mathbf{R}$ & 1 & $.380^{* * *}$ & .181 & $.285^{* *}$ & $.307^{* *}$ & $.426^{* * *}$ \\
\hline $\bar{A}$ & $.318^{* *}$ & 1 & $.318^{* F}$ & $.449^{* * *}$ & $.487^{* *}$ & $.481^{* \cdots F}$ \\
\hline $\mathbf{C}$ & .181 & $.318^{* *}$ & 1 & $.584^{* *}$ & $.523^{* *}$ & $.582^{* *}$ \\
\hline $\mathbf{S}$ & $.285^{* *}$ & $.449^{* *}$ & $.584^{* *}$ & 1 & $.748^{* * *}$ & $.474^{* *}$ \\
\hline $\mathbf{E}$ & $.307^{* *}$ & $.487^{* *}$ & $.523^{* *}$ & $.748^{* *}$ & 1 & $.568^{* *}$ \\
\hline I & $.426^{* *}$ & $.481^{* *}$ & $.582^{* * *}$ & $.474^{* *}$ & $.568^{* *}$ & 1 \\
\hline
\end{tabular}

As seen in Table VIII, inter-correlations among the three highest of Holland's personality styles of students were as follows:

- AIR (Artistic, Investigative and Realistic) which correlated negatively with CES (Conventional, Enterprising and Social)

- ESA (Enterprising, Social and Artistic) which correlated negatively with IRC (Investigative, Realistic and Conventional)

- SAI (Social, Enterprising and Investigative)which correlated negatively with RCE (Realistic, Conventional and Enterprising)

TABLE VIII. INTER-CORRELATIONS AMONG HOLLAND's PERSONALITY STYLES

\begin{tabular}{|c|c|c|c|c|c|c|}
\hline $\begin{array}{l}\text { Personality } \\
\text { Styles }\end{array}$ & AIR & ESA & CES & SAI & RCE & IRC \\
\hline AIR & 1 & -.163 & $-.334-^{* *}$ & .109 & .049 & -.059 \\
\hline ESA & -.163 & 1 & -.117 & .052 & -.060 & $-.320-^{* *}$ \\
\hline CES & $-.334-^{* *}$ & -.117 & 1 & -.069 & .069 & -.161 \\
\hline SAI & .109 & .052 & -.069 & 1 & $-.211-^{*}$ & .041 \\
\hline RCE & .049 & -.060 & .069 & $-.211-$ & 1 & -.100 \\
\hline IRC & -.059 & $-.320{ }^{* *}$ & -.161 & .041 & -.100 & 1 \\
\hline
\end{tabular}

C. Comparison of personality styles (percentage) between

Information systems (IS), Computer science (CS) and

preparatory yearof distance learning students

Comparison of student personality styles (percentage) results from the Holland survey are shown in Table IX and Figure 2.

Based on the percentage of each personality style exhibited, it was found that students of CS and IS were different from preparatory year distance learning students in their personality styles (ESA). However, CSIS and preparatory year distance learning students were similar in terms of percentage of other personality styles represented (CES, SAI, IRC, RCE, and AIR).

TABLE IX. COMPARISON OF STUDENT PERSONALITY STYLES (PERCENTAGE)

\begin{tabular}{|c|c|c|c|c|c|c|}
\hline & \multicolumn{5}{|c|}{ Personality Styles } \\
\hline Groups & ESA & CES & SAI & IRC & RCE & AIR \\
\hline CS Students & $30 \%$ & $48 \%$ & $33 \%$ & $22 \%$ & $11 \%$ & $15 \%$ \\
\hline $\begin{array}{c}\text { IS Students } \\
\text { Distance learning } \\
\text { Students }\end{array}$ & $25 \%$ & $29 \%$ & $25 \%$ & $14 \%$ & $14 \%$ & $25 \%$ \\
\hline
\end{tabular}




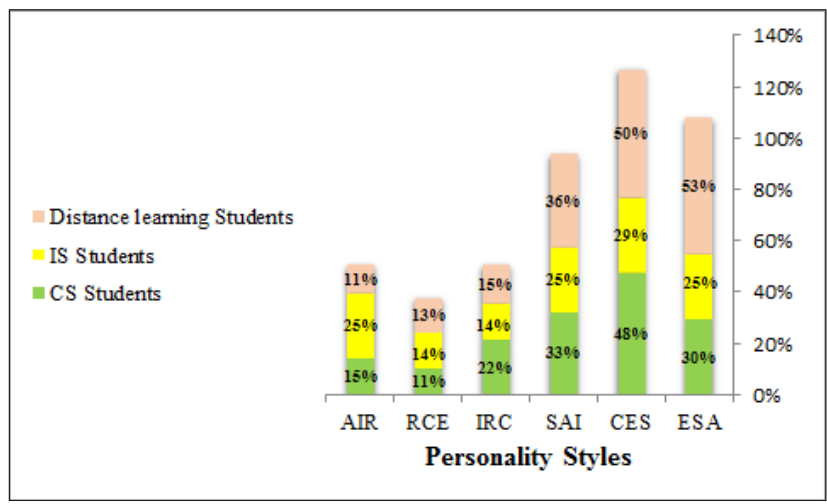

Fig. 2. Comparison of student personality styles (percentage)

Based on ANOVA, analyses were performed on the Holland survey with regard to differences in the six broad personality types between IS,CS and preparatory year distance learning students (Table X). IS,CS and distance learning students differed significantly on ESA factors $(\mathrm{F}(2,114)=$ $4.32, \mathrm{P}=0.02<0.05$ ), indicating that IS, CS and preparatory year distance learning students differed in the ESA style, but were similar in the other broad personality categories AIR, CES, SAI, RCE and IRC.

TABLE X. COMPRESSION BETWEEN THREE GROUPS (ANOVA)

\begin{tabular}{|c|c|c|c|c|c|c|}
\hline $\begin{array}{c}\text { Personality } \\
\text { Styles }\end{array}$ & & \begin{tabular}{|l|} 
Sum of \\
Squares
\end{tabular} & df & \begin{tabular}{|l|} 
Mean \\
Square
\end{tabular} & $\mathbf{F}$ & Sig. \\
\hline \multirow[t]{3}{*}{ AIR } & $\begin{array}{c}\text { Between } \\
\text { Groups }\end{array}$ & .36 & 2.00 & .18 & 1.39 & .25 \\
\hline & $\begin{array}{l}\text { Within } \\
\text { Groups }\end{array}$ & 14.87 & 114.00 & .13 & & \\
\hline & Total & 15.23 & 116.00 & & & \\
\hline \multirow[t]{3}{*}{ ESA } & $\begin{array}{c}\text { Between } \\
\text { Groups }\end{array}$ & 1.99 & 2.00 & 1.00 & 4.32 & .02 \\
\hline & $\begin{array}{l}\text { Within } \\
\text { Groups }\end{array}$ & 26.32 & 114.00 & .23 & & \\
\hline & Total & 28.31 & 116.00 & & & \\
\hline \multirow[t]{3}{*}{ CES } & $\begin{array}{c}\text { Between } \\
\text { Groups }\end{array}$ & .93 & 2.00 & .47 & 1.90 & .15 \\
\hline & $\begin{array}{l}\text { Within } \\
\text { Groups }\end{array}$ & 27.96 & 114.00 & .25 & & \\
\hline & Total & 28.89 & 116.00 & & & \\
\hline \multirow[t]{3}{*}{ SAI } & $\begin{array}{c}\text { Between } \\
\text { Groups }\end{array}$ & .21 & 2.00 & .11 & .48 & .62 \\
\hline & $\begin{array}{l}\text { Within } \\
\text { Groups }\end{array}$ & 25.44 & 114.00 & .22 & & \\
\hline & Total & 25.66 & 116.00 & & & \\
\hline \multirow[t]{3}{*}{ RCE } & $\begin{array}{c}\text { Between } \\
\text { Groups }\end{array}$ & .01 & 2.00 & .01 & .06 & .94 \\
\hline & $\begin{array}{l}\text { Within } \\
\text { Groups }\end{array}$ & 13.06 & 114.00 & .11 & & \\
\hline & Total & 13.08 & 116.00 & & & \\
\hline \multirow[t]{3}{*}{ IRC } & $\begin{array}{c}\text { Between } \\
\text { Groups }\end{array}$ & .13 & 2.00 & .06 & .45 & .64 \\
\hline & $\begin{array}{l}\text { Within } \\
\text { Groups }\end{array}$ & 15.79 & 114.00 & .14 & & \\
\hline & Total & 15.91 & 116.00 & & & \\
\hline
\end{tabular}

\section{DISCUSSION}

This study deals with many important issues regarding the results of the Holland test and can help students to identify the career cluster(s) in which they would have the most interest and satisfaction. In discussing the results cited from Table3to Table 9, the following themes were evident:

- The three most frequent Holland codes for students (IS, CS and preparatory year distance learning students) were CES (Conventional, Enterprising and social). RCE was the least frequent of the overall personality styles of students. Suitable careers for students with high scores in code CES: Cost Accountant, Congressional-District Aide.

- The three most frequent Holland codes for CS students were CES (Conventional, Enterprising and Social). RCE was the least frequent of the overall personality styles of CS students. The three highest frequency Holland codes for IS students were similar to the three highest of CS students and three lowest frequency Holland codes for CS students were similar to the lowest frequency Holland codes for IS students. Suitable careers for CS and IS students with high scores in code CES: Cost Accountant, Congressional-District Aide.

- The three most frequent Holland codes for distance learning students were ESA (Enterprising, Social and Artistic. Suitable careers for preparatory year distance learning students: Customer Service Manager, Entrepreneur, Foreign Service Officer, Politician, Sales Manager, Advertising Executive, Branch Manager, Buyer, Social Service Director. AIR (Artistic, Investigative and Realistic) was the least frequent of the overall personality styles of distance learning students.

- It was noted from the inter-correlations among Holland's personality styles that Realistic correlated positively with Artistic, Social, Enterprising and Investigative, but not with Conventional. The results have several significant implications for students, for example, the career of Realistic students suitable for Artistic, Social, and Enterprising students.

- It was also noted from inter-correlations among Holland's personality styles that AIR (Artistic, Investigative and Realistic) correlated negatively with CES (Conventional, Enterprising and Social), ESA (Enterprising, Social and Artistic) correlated negatively with IRC (Investigative, Realistic and Conventional), and SAI (Social, Enterprising and Investigative) correlated negatively with RCE (Realistic, Conventional and Enterprising). The results have several significant implications for students. A negative correlation indicates an inverse relationship whereas AIR (Artistic, Investigative and Realistic)styles increase, the CES and ESA styles decrease. This means that the career of AIR students is not suitable for CES and ESA students.

- The personality type categories between IS, CS and preparatory year distance learning students were 
different in ESA style from the ANOVA test, but similar in the other broad personality types AIR, CES, SAI, RCE and IRC.

\section{CONCLUSION}

This paper has discussed the Holland test in relation to observations indicating that some students have difficulty in determining a suitable career. As this affects their performance, productivity and satisfaction, it is critically important to understand how to find a career that fits their personality. The results may be useful for evaluating their problem in order to determine a suitable career according to the six personality types of Holland's theory. This paper also compared personality types of female IS students with the personality types of CS students and distance learning students in Saudi Arabia. It was noted from the results the personality type categories between IS, CS and preparatory year distance learning students were different in ESA style, but similar in the other broad personality types AIR, CES, SAI, RCE and IRC.

\section{REFERENCES}

[1] Anderson, N., Herriot, P. \&Hodgkinson, G. P. (2001). The practitionerresearcher divide industrial, work and organizational (IWO) psychology: Where we are now, and where do we go from here? Journal of Occupational and Organizational Psychology, Vol. 74 No 4, pp. 391411.

[2] Cruickshank, C. S. (2005). A Test of Holland's Congruence Assumption Using Four-Year Public College Students in Ohio. Ohio: The University of Toledo.

[3] Davidson M (2010). Factors Affecting Career Choices. Retrieved January 20, 2011, from www.ehow.com: http://www.ehow.com/list_6685028_factors-affectingcareerchoices.html

[4] Dunnette, M. D. (1990). Blending the science and practice of industrial and organizational psychology: Where are we and where are we going? In M. D. Dunnette and L. M. Hough (Eds.) Handbook of industrial and organizational psychology (Vol. 1, pp.127). Palo Alto, CA: Consulting Psychologists Press.

[5] Edwards, J.R. (1991). Person-job fit: a conceptual integration, literature review and methodological critique. International Review of Industrial/Organizational Psychology, Vol. 6, pp. 283-357.

[6] Ekehammer, B. (1974). Interactionism in personality from a historical perspective. Psychological Bulletin, Vol. 81, pp. 1026-1048.

[7] Equal Employment Opportunity Commission (1978). The Office of Personnel Management, U.S. Department of Justice and U.S. Department of Labor (1979). Uniform Guidelines on Employee Selection Procedures.41 CFR Part 603 (1978).

[8] Ferguson, I. (2000). Holland's Theory Discussed. Retrieved September 28, 2010, from suite101:http://www.suite101.com/article.cfm/foundations_of_psycholo gy/48558/1

[9] Gioia, C. (2010). Why people make bad career choices. Retrieved September 27, 2010, from http://www.helium.com: http://www.helium.com/items/1903238-why-people-make-badcareerchoices
[10] Harvey, R. J. (1991).Job analysis.In M. D. Dunnette\& L. M. Hough (Eds.), Handbook of industrial and organizational psychology (2nd ed., Vol. 2, pp. 71-163). Palo Alto, CA: Consulting Psychologists Press.

[11] Harvey, R. J. \& Wilson, M. A. (2000). Yes Virginia, there is an objective reality in job analysis. Journal of Organizational Behavior, Vol. 21, pp. 829-854.

[12] Holland, J. L. (1973).Making vocational choices: A theory of careers. Englewood Cliffs, NJ: Prentice-Hall. Johansson, C.B. \& Campbell, D.P. (1971).Stability of the SVIB for men. Journal of Applied Psychology, 55, 34-36.

[13] Holland, J. L. (1985). Vocational Preference Inventory manual (1985 ed.). Odessa, FL: Psychological Assessment Resources, Inc.

[14] Holland, J.L. (1997). Making vocational choices (Third Edition); a theory of vocational personalities and work environments. Odessa, FL: Psychological Assessment Resources, Inc.

[15] Kelso, S. R., Ganong, A. H. and Brown, T. (1986).HebbianSynapses in the Hippocampus. proc. natl. acad. sci. usa 83: 5326-5330.

[16] Kristof, A. (1996). Person-organization fit: an integrative review of its conceptualizations, measurement, and implications. Personnel Psychology, Vol. 49, pp. 1-49.

[17] Lewin, K. (1935). Dynamic theory of personality. New York: McGrawHill.

[18] Miller, M. J. (1994). A "circuitous" test of Holland's theory. Journal of Employment Counselling, 31, 137-143.

[19] Murray, H.A. (1938). Explorations in Personality. Boston, MA: Houghton Mifflin.

[20] Parsons, F. (1909).Choosing a vocation. Boston: Houghton-Mifflin.

[21] Pervin, L.A. (1968). Performance and satisfaction as a function of individual-environment fit. Psychological Bulletin, Vol. 69, pp. 56-68.

[22] Ryan, A.M. \&Snackett, P.R. (1987). A survey of individual assessment practices by I/O psychologists. Personnel Psychology, Vol. 40, pp. 455488.

[23] Rynes, S.L. \&Gerhart, B. (1990). Interviewer assessments of applicant "fit": An exploratory investigation. Personnel Psychology, Vol. 43, pp. 13-35.

[24] Sackett, P. R. (1994) Integrity testing for personnel selection. Current Directions in Psychological Science,Vol. 3, pp. 73-76.

[25] Saks, A.M. \&Ashforth, B.E. (1997). A longitudinal investigation of the relationships between job information sources, applicant perceptions of fit, and work outcomes. Personnel Psychology, Vol. 50, pp. 395-426.

[26] Schneider, B. (1987). The people make the place. Personnel Psychology, Vol. 40, pp. 437-454.

[27] Schreiner, E. (2010). Factors Influencing Employment Choices after High School. Retrieved January 20, 2011, from www.ehow.com: http://www.ehow.com/list_6578688_factors-choices-after-high school.html.

[28] Sekiguchi, T. (2004). Person-organization fit and person-job fit in employee selection: A review of the literature. Osaka KeidaiRonshu, Vol. 54 No. 6, pp. 179-196.

[29] Werbel, J.D. \& Gilliland, S.W. (1999). Person-environment fit in the selection process. In Ferris G.R. (Ed.).Research in Personnel and Human Resource Management, vol. 17, pp. 209-243. Stamford, CT: JAI Press.

[30] Zaidi. F. B. Iqbal, S. (2012), Impact of career selection on job satisfaction in the service industry of Pakistan, African Journal of Business Management Vol. 6 (9), pp. 3384-3401. 